\title{
Dakwah Kontemporer dan Radikalisme Agama di Bulukumba
}

\author{
Mahmuddin \\ UIN Alauddin Makassar \\ mahmuddin.dakwah@uin-alauddin.ac.id
}

\begin{abstract}
The article aims to understand the application of contemporary dakwah in Bulukumba as an effort to tackle religious radicalism. This highlighted from a characteristic contemporary priests, contemporary dakwah materials and media of contemporary dakwah and the role of dakwah in counteracting religious radicalism in Bulukumba district of South Sulawesi. The result of this research shows that in general dai (priests) including contemporary dai. At this point, it can be said that one of the characters contemporary dakwah is contemporary priests themselves. The priests, mostly still focused on the traditional ways in presenting Islam when they give presentations. Meanwhile, matters such as contemporary medium had not been fully employed well. Ultimately, the priests play important roles in order to counter and prevent religious radicalism, and they have the role to explain proportional religious thoughts.
\end{abstract}

\begin{abstract}
Abstrak
Artikel ini bertujuan untuk mengetahui penerapan dakwah kontemporer di Bulukumba sebagai upaya untuk menangkal radikalisme agama. Hal ini disorot dari sudut karakteristik dai kontemporer, materi dakwah kontemporer dan media dakwah kontemporer serta peran dakwah dalam menangkal radikalisme agama di Kabupaten Bulukumba.Hasil penelitian ini menunjukkan bahwa pada umumnya dai termasuk dai kontemporer. Oleh karena itu, dapat dikatakan bahwa salah satu karakter dakwah kontemporer adalah dai yang kontemporer. Dai dalam menyampaikan materi dakwah kontemporer pada umumnya masih berfokus pada materi sistem tradisional. Sedangkan kaitannya dengan media kontemporer, para dai belum sepenuhnya menggunakannya dengan baik. Kaitannya dengan peran dakwah dalam menangkal radikalisme agama adalah pada umumnya dai sangat berperan dan berupaya untuk menjelaskan agama secara proporsional.
\end{abstract}

Keywords contemporary dakwah, religious radicalism, Bulukumba, Islam. 


\section{A. Pendahuluan}

Dakwah kontemporer adalah dakwah yang menggunakan fasilitas teknologi modern dengan tiga indikator yaitu dai yang memanfaatkan teknologi modern, materi dakwah yang kontemporer dan dai menggunakan media kontemporer. Dengan adanya dakwah kontemporer, tidak berarti harus meninggalkan dakwah konvensional secara total, tetapi adanya upaya menyeimbangkan penggunaannya dan memperhatikan obyek dakwahnya.

Teknologi di bidang komputer, mempermudah para dai dalam melaksanakan dakwah dan penyebaran dakwah ke seluruh khalayak, sebab dengan teknologi, para dai diharapkan mampu memanfaatkan komputer dengan baik, sehingga mereka dapat membuka Holy Qur'an, holy Hadits dan masih banyak fasilitas yang lagi berkembang dewasa ini.

Media dakwah yang pada awalnya lebih banyak menggunakan media tradisional, berkembang menjadi lebih banyak variasinya dengan menggunakan sentuhan-sentuhan teknologi media massa modern, baik dengan media cetak maupun dengan media elektronik yang variatif pula. ${ }^{1}$

Peran ICT (Information Communication Tehnology) sebagai media telah memberikan stimulan dalam berbagai sendi kehidupan. ${ }^{2}$ HP sudah menjadi sentrum medium dakwah oleh para dai, mengingat kehadiran media ini telah sampai ke masyarakat suku terasing atau pelosok desa terpencil sepanjang tersedia jaringan satelit cellular yang ia gunakan. HP dapat dimaksimalkan sebagai medium dakwah.

Wrigh membagi media komunikasi berdasar pada sifat dasar pemirsa, sifat dasar pengalaman komunikasi dan sifat dasar pemberi informasi. Lasswell mencatat ada tiga fungsi media massa: pengamatan lingkungan, korelasi bagian-bagian dalam masyarakat untuk merespons lingkungan, dan penyampaian warisan masyarakat dari satu generasi ke generasi selanjutnya. Selain ketiga fungsi ini, Wrigh menambahkan fungsi keempat yaitu hiburan. ${ }^{3}$ Media memiliki dwi fungsi yaitu fungsi yang baik dan fungsi yang tidak baik, hal ini tergantung siapa di balik media tersebut.

\footnotetext{
${ }^{1}$ Ahmad Anas, Paradigma Dakwah Kontemporer: Aplikasi Teoritis dan Praktis Dakwah Sebagai Solusi Problematika Kekinian. (Semarang: Pustaka Rizki Putra, 2006 ), h. 68

${ }^{2}$ Suf Kasman, Pers dan Pencitraan Umat Islam di Indonesia; Analisis Isi Pemberitaan Harian Kompas dan Republika. (Cet. I; Jakarta: Balai Litbang dan Diklat Kementerian Agama RI, 2010), h. 273.

${ }^{3}$ Werner J. Severin dan James W. Tankard, Jr. Communication Theories: Origins, Methods, \& Usis in the Mass Media, terj. Sugeng Hariyanto (Cet. IV; Jakarta: Kencana, 2009), h. 386.
} 
Karena ia bagaikan pisau bermata dua, ia akan menjadi baik bila dikendalikan oleh orang baik, tetapi sebaliknya ia akan jadi jahat bila dikendalikan oleh orang jahat.

Sementara itu, pengenalan dan pemahaman syariat Islam kepada umat secara tepat, diperlukan strategi dakwah yang tepat pula, agar pelaksanaannya dapat mencapai sasaran yang tepat. Untuk itu, diperlukan perencanaan dakwah yang benar-benar berangkat dari hasil pengamatan dan analisis tentang kondisi obyektif mad'u.

Menurut Anwar Arifin bahwa unsur dakwah mulai dari dai atau mubalig serta organisasi atau lembaganya, pesan, metode dan media yang sesuai dengan kondisi dan situasi khalayak. ${ }^{4}$

Dengan penggunaan media dakwah yang serba canggih ini, maka tidak menutup kemungkinan adanya gerakan penggunaan media kontemporer secara terselubung dalam memengaruhi masyarakat sebagai upaya radikalisme agama. Untuk itu, dengan mengkaji lebih dalam aplikasi dakwah kontemporer ini di Bulukumba menjadi hal yang penting terutama dalam upaya menangkal radikalisme agama sejak awal.

Sehubungan dengan hal di atas, Abu Rokhmad menyebutkan bahwa lembaga-lembaga pendidikan diduga tidak kebal terhadap pengaruh ideologi radikal. Dikatakan bahwa terdapat beberapa guru mengakui adanya konsep Islam radikal yang mungkin menyebar di kalangan siswa karena kurangnya pengetahuan keagamaan. Unit-unit kajian Islam di sekolah berkembang baik namun tidak ada jaminan adanya kekebalan dari radikalisme karena proses belajarnya diserahkan kepada pihak ketiga. ${ }^{5}$ Pandangan Rokhmad tersebut sebagaimana terungkap pada penelitiannya menggambarkan adanya kecenderungan siswa membenci agama. Oleh karena itu, perlu ada kewaspadaan agar siswa tidak dipengaruhi oleh radikalisme agama.

Sementara itu Hasyim Muhammad dkk. dalam penelitiannya mengemukakan bahwa pesantren memiliki perspektif tersendiri terhadap radikalisme agama dan kekerasan. Pandangan Pesantren Soko Tunggal disebutkan bahwa gerakan radikal atas nama agama merupakan bentuk kesalahpahaman agama. Islam radikal umumnya didasarkan pada pemahaman Wahabi, sehingga sikap dan perilaku dipengaruhi oleh

\footnotetext{
${ }^{4}$ Anwar Arifin, Dakwah Kontemporer: Sebuah Studi Komunikasi. (Cet. I; Yogyakarta: Graha Ilmu, 2011), h. 233.

${ }_{5}^{5} \mathrm{Abu}$ Rokhmad, 2012, Radikalisme Islam Dan Upaya Deradikalisasi Paham Radikal, Jurnal Walisongo, Volume 20, Nomor 1, h. 1
} 
Wahabi. Menurut Wahabi, bid'ah dalam agama adalah bentuk penodaan dan penolakan yang harus diperangi. Pesantren menganggap bahwa Pancasila dan UUD 1945 merupakan bentuk penegakan hukum Islam yang aktual. Karena di Pesantren Soko Tunggal ini ingin mempertahankan nilainilai moderatisme dan mengembangkan kehidupan multikultural yang damai. ${ }^{6}$ Pandangan ini memiliki kekuatan tersendiri dalam memahami gerakan radikal atas nama agama, sebab pandangan tidak setuju bila gerakan radikal atas nama agama dijadikan sebagai alat untuk tujuan tertentu.

Berbeda halnya dengan pandangan Abdul Munip. Abdul Munip menyebutkan bahwa tidak bisa dipungkiri, banyak umat muslim Indonesia memahami Islam dalam perspektif radikalisme. Mereka menggunakan beberapa cara untuk menyebarkan radikalisme ini melalui organisasi kader, ceramah di masjid-masjid yang dikelola dengan kendali mereka, penerbitan majalah, booklet dan buku, dan melalui berbagai situs di internet. Akibatnya, radikalisme Islam telah memasuki sebagian besar sekolah di beberapa daerah. Jika hal ini tidak segera diantisipasi, maka dapat membantu dalam menumbuhkan sikap intoleransi di kalangan siswa yang bertentangan dengan tujuan pendidikan agama itu sendiri. ${ }^{7}$ Kewaspadaan tersebut sangat beralasan, sebab usia sekolah adalah usia yang sangat mudah terpengaruh dan mudah diisi dengan doktrin keagamaan.

Abu Rokhmad menyebutkan bahwa wajah Islam moderat di Indonesia kian berubah sejak rezim Orde Baru tumbang pada 1998. Kelompok-kelompok muslim garis keras tumbuh subur di masyarakat. Mereka tidak segan berdakwah dengan cara kekerasan bahkan terorisme. Radikalisme menjadi masalah penting bagi umat Islam Indonesia dewasa ini. Keterlibatan kiai dalam menangani masalah radikalisme (deradikalisasi) sangat diharapkan. Artikel ini mengkaji mengenai pandangan kiai tentang akar radikalisme Islam dan strategi kiai dalam melakukan deradikalisasi paham Islam radikal. Kesimpulan artikel ini adalah: Pertama, akar radikalisme disebabkan dua faktor besar, yaikni faktor pemahaman agama yang kurang tepat dan faktor politik yang

\footnotetext{
${ }^{6}$ Hasyim Muhammad, Khoirul Anwar, Misbah Zulfa E., 2015, Diskursus Deradikalisasi Agama: Pola Resistensi Pesantren Terhadap Gerakan Radikal, Jurnal Walisongo, Volume 23, Nomor 1, h. 1.

${ }^{7}$ Abdul Munip, 2012, Menangkal Radikalisme Agama di Sekolah, Jurnal Pendidikan Islam : Volume I, Nomor 2, h. 1
} 
berhubungan isu nasional dan global. Kedua, terdapat dua model deradikalisasi, tergantung sifat dari pelaku radikalisme: deradikalisasi pencegahan, dan deradikalisasi penyembuhan. ${ }^{8}$ Gejala tersebut menjalar ke seluruh negeri, termasuk di Kabupaten Bulukumba, Provinsi Sulawesi Selatan.

Perdebatan tersebut menunjukkan bahwa masalah radikalisme agama memerlukan kajian dan penelitian yang mendalam agar akar permasalahan dapat terungkap dan mendapatkan solusi terbaik bagi agama dan bangsa Indonesia.

Untuk menjawab latar belakang masalah tersebut, maka diperlukan kajian yang terkait dengan karakteristik dai kontemporer di Bulukumba, rumusan materi dakwah kontemporer di Bulukumba, penerapan media dakwah kontemporer di Bulukumba, dan peran dakwah kontemporer dalam menangkal radikalisme agama di Bulukumba.

Kajian ini bertujuan untuk mengetahui karakteristik dai kontemporer di Bulukumba, mengetahui materi dakwah kontemporer di Bulukumba, mengetahui penggunaan media dakwah kontemporer di Bulukumba, mengetahui peran dakwah kontemporer dalam menangkal radikalisme agama di Bulukumba.

Hasil penelitian ini diharapkan bergunaan bagi dai dalam mengenal dan menerapkan dakwah kontemporer sebagai upaya dalam menangkal radikalisme agama dan sebagai sumbangsih teoretis dalam pelaksanaan dakwah di Bulukumba. Di samping itu dapat mendorong para subyek dakwah untuk senantiasa melaksanakan kegiatan dakwah dengan mengangkat tema-tema dakwah kontemporer dan menggunakan media dakwah kontemporer serta upaya menangkal radikalisme agama di Bulukumba.

Teknik pengumpulan data melalui interview, observasi, dokumentasi dan angket. Angket ini digunakan untuk melengkapi data. Penulis menggunakan angket adalah untuk mendapatkan informasi dari masyarakat yang berkaitan dengan pandangan mereka tentang aplikasi dakwah kontemporer dalam menangkal radikalisme agama di Bulukumba.

Sumber data penelitian ini ialah mubalig atau dai di Bulukumba. Memperhatikan dari inti permasalahan yang dikaji, yaitu menyangkut

\footnotetext{
${ }^{8} \mathrm{Abu}$ Rokhmad, 2014, Pandangan Kiai Tentang Deradikalisasi Paham Islam Radikal di Kota Semarang, Jurnal “Analisa" Volume 21 Nomor 01, h. 1
} 
dakwah kontemporer, meliputi dai kontemporer, materi kontemporer dan media kontemporer serta upaya menangkal radikalisme agama, maka penulis menggunakan pendekatan sosiologis yaitu suatu pendekatan yang menganalisa kondisi sosial masyarakat secara keseluruhan antara orang-orang dalam masyarakat. Di dalam menelaah masyarakat manusia akan banyak berhubungan dengan kelompokkelompok sosial, baik yang kecil seperti kelompok keluarga atau kelompok desa, mayarakat kota, bangsa dan lain-lain. ${ }^{9}$ Pergaulan tersebut menghasilkan pandangan-pandangan mengenai kebaikan dan keburukan.

\section{B. Dakwah Kontemporer dan Radikalisme Agama}

A. Aplikasi Dakwah Kontemporer

1. Media Dakwah Kontemporer dan Karakteristik Responden

a. Media Cellullar

Berdakwah lewat SMS, MMS, e-Mail, you Tube, Twiter, NSP, BBM, FB, WA dan Al-Quran seluler merupakan cara berdakwah yang lebih murah dan mudah. Murah karena ada beberapa perusahaan yang menawarkan paket murah dan bahkan gratis. Selain murah juga mudah dijangkau dalam waktu hitungan detik pesan yang dikirim dapat sampai kepada tujuan. Namun bila dilihat dari efek masih relative, karena media cellular, pelaksanaan dakwah masih sering dianggap sebagai bahan mainan dan cerita lucu belaka. Walaupun demikian dakwah melalui media sellular sudah menjadi tren manusia modern dewasa ini.

Peluang dakwah lewat media cellular semakin berkembang, dewasa ini sedang dikembangkan media yang semakin memudahkan dalam berkomuniksi.

Dengan demikian, media sellular dengan segala programnya dapat digunakan untuk berdakwah dengan jalan mengirim pesan yang mengajak kepada orang lain untuk berbuat baik. Kesemuanya disebut dengan dakwah tulisan lewat eletronik.

Dewasa ini telah muncul cellular Alquran yang memudahkan bagi umat Islam untuk menemukan ayat-ayat Alquran dengan mudah. Kemudahan ini membuat umat Islam semakin dekat dengan pedoman hidupnya. Oleh karena itu, seyogyanya cellular ini dimanfaatkan semaksimal mungkin demi kedekatan umat kepada Khalik penciptanya.

\footnotetext{
${ }^{9}$ Soerjono Soekanto, Sosiologi Suatu Pengantar, (Jakarta: Raja Grafinda Persada, 2007),
} h. 102. 
Olehnya itu, berdakwah lewat media sellular hendaknya setiap pemiliknya memanfaatkannya dengan berdakwah guna menyebarluaskan agama dalam kehidupan seorang muslim tetap dikobarkan sebagai upaya transformasi pesan-pesan ilahiyah kepada seluruh umat manusia.

Keberadaan media cellular bagi masyarakat Indonesia, berdampak pada mudahnya pelaksanaan dakwah, khususnya bagi mereka yang memiliki kemampuan dan berkeinginan untuk berdakwah. Eksistensi dakwah dalam kehidupan manusia sangat urgen hal ini dapat diperkuat dalam salah satu firman Allah pada Q.S. Saba': 28.

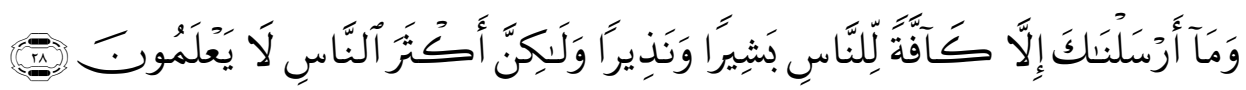

Terjemahnya:

Dan Kami tidak mengutus kamu, melainkan kepada umat manusia seluruhnya sebagai pembawa berita gembira dan sebagai pemberi peringatan, tetapi kebanyakan manusia tiada mengetahui. ${ }^{10}$

b. Media Televisi

Dakwah kontemporer dewasa ini mulai memperlihatkan jati dirinya dalam arti bahwa mubalig mulai melirik dan media televisipun mulai mendekatkan diri terhadap pengelola dakwah.

Dengan demikian dakwah tidak bisa lagi dikerjakan dengan caracara tradisional, akan tetapi adanya rekonstruksi dan reformulasi stategi dakwah dalam menjawab berbagai tantangan masa kini yang kian hari semakin kompleks masalah yang dihadapi oleh umat manusia pada umumnya dan umat Islam khususnya.

c. Media Radio

Salah satu kelebihan medium radio dibanding dengan medi lainnya, ialah cepat dan mudah dibawa ke mana-mana. Radio bisa dinikamati sambil mengerjakan perkerjaan lain, suatu hal yang tidak mungkin terjadi pada media lain. ${ }^{11}$ Radio adalah siaran atau pengiriman suara atau bunyi melalui udara. Oleh sebab itu, segala sesuatu dapat disiarkan melalui radio. ${ }^{12}$

\footnotetext{
${ }^{10}$ Kalla Group, Alquran dan Terjemahnya, (Semarang, PT. Karya Toha Putra, 2015), h. 431.

${ }^{11}$ Hafied Cangara, Komunikasi Politik, Teori dan Strategi, (Cet. III; Jakarta: Rajawali Pers, 2011), h. 140-141.

${ }^{12}$ Anwar Arifin, Dakwah Kontemporer: Sebuah Studi Komunikasi, (Cet I; Yogyakarta: Graha Ilmu, 2011), h. 108.
} 
Sebelum menyampaikan ceramah di studio yang telah disediakan, maka seorang mubalig hendaknya berada di tempat 15-30 menit sebelum acara dimulai. Waktu 15-30 menit tersebut dapat digunakan untuk berkomunikasi dengan operator radio dan juga kepada petugas lainnya sehingga ketika siaran tidak mengalami kendala yang berkaitan dengan waktu.

d. Karakteristik Responden

Karakteristik akar katanya adalah karakter dapat berarti sifat-sifat kejiwaan, akhlak atau budi pekerti yang membedakan seseorang dengan orang lain; tabiat; watak. Karakteristik dapat berarti mempunyai sifat khas sesuai dengan perwatakan tertentu. ${ }^{13}$

Adapun mengenai karakteristik responden adalah sifat-sifat khas bagi responden. Karakter yang melekat pada responden adalah:

1) Usia dan Jenis kelamin responden

Usia dan jenis kelamin responden adalah mereka yang berjenis kelamin laki-laki yakni mencapai 23 orang atau 82,14\%, sedangkan perempuan hanya mencapai 5 orang atau $17,86 \%$. Sedangkan yang berusia antara 30-39 sebanyak 7 orang atau 25\%, yang berusia antara 40-49 tahun yaitu sebanyak 8 orang atau mencapai $28,56 \%$, sedang yang berusia antara 50-59 tahun yaitu sebanyak 9 orang atau 32,14\%. Dan berusia antara 60-69 tahun mencapai 3 orang atau 10,71\%, serta yang berusia 70 tahun ke atas hanya 1 orang atau 3,57\%. Dengan demikian dapat dipahami bahwa responden berusia produktif yaitu yang berusia antara 30-59 tahun sebanyak 24 orang atau $85,71 \%$.

Memperhatikan hal tersebut menunjukkan bahwa responden cukup variatif di dalam memberikan tanggapannya pada penilaian yang berkaitan dengan dakwah kontemporer di Bulukumba.

2) Pendidikan responden.

Tingkat pendidikan masyarakat yang menjadi responden yang terbanyak adalah tingkat S1 mencapai 21 orang atau $75 \%$ dan SLTA 1 orang atau 3,57\% sedang lulusan S2 mencapai 6 orang atau 21,43\%. Hal tersebut dapat memberikan gambaran yang jelas dalam tingkat akurasi data yang diperoleh.

Dengan demikian tingkat pengetahuan responden terhadap masalah yang dibahas adalah cukup memadai untuk menjawab berbagai pertanyaan yang disuguhkan, dan tingkat akurasinya cukup tinggi.

\footnotetext{
${ }^{13}$ Tim Penyusun Kamus Pusat Pembinaan dan Pengembangan Bahasa, Kamus Besar Bahasa Indonesia, (Cet. II; Jakarta: Balai Pustaka, 1989), h. 389.
} 


\section{Karakteristik Dakwah Kontemporer}

a. Karakteristik Dai Kontemporer di Bulukumba

Karakteristik dai kontemporer merupakan karakter dai di Bulukumba yang dapat dilihat pada pengenalan terhadap istilah dai kontemporer, membaca konsep atau tidak dalam melaksanakan dakwah, penggunaan busana di dalam berdakwah, serta buku-buku rujukan yang digunakan. Data menunjukkan terpenuhinya sebagian besar syarat tersebut. Responden secara keseluruhan telah mengenal istilah dakwah kontemporer, hal ini terindikasi bahwa dakwah kontemporer telah berjalan di Bulukumba. Itulah sebabnya, dai dapat dijadikan sebagai contoh teladan dalam berdakwah.

Pada teori citra dai dikatakan bahwa dai merupakan pola anutan di dalam berbagai hal, khususnya yang berkaitan kepengikutan mad'u dalam pelaksanaan ibadah dan masalah lainnya. Oleh karena itu, dai sebagai subyek dakwah melekat pada dirinya sebagai sosok manusia teladan yang patut dicontoh oleh umat dan dai diharapkan memiliki kredibilitas yang tinggi.

Salah satu ciri dai kontemporer adalah dai yang senantiasa melaksanakan dakwah bil lisan tidak membaca konsep secara monoton. Dari data dikumpul melalui angket, ternyata terdapat 16 orang atau $57,14 \%$ dai yang tidak membaca konsep secara monoton, namun masih terdapat 12 orang atau $42,86 \%$ yang masih menggunakan konsep secara monoton dalam ceramahnya. Hal ini menunjukkan bahwa di Bulukumba para dai lebih banyak yang tergolong dai kontemporer dibandingkan dengan dai yang tidak tergolong dai kontemporer atau tradisional.

Selain itu, ciri dai kontemporer adalah dai yang tidak mengharuskan menggunakan busana seperti memakai pakaian sarung, kopia, surban, baju koko dalam berdakwah. Data diperoleh bahwa dai yang tidak mengharuskan menggunakan pakaian tersebut mencapai 16 orang atau $57,14 \%$, tetapi yang masih tetap bertahan pada keharusan dalam penggunaan pakaian sarung, kopia, surban, baju koko dalam berdakwah adalah mencapai 12 orang atau $42,86 \%$.

Dari data tersebut dapat dipahami bahwa dai yang ada di Bulukumba cenderung atau lebih banyak yang telah mengkuti ciri dai kontemporer dibandingkan dengan yang masih tradisonal.

Dai yang masih menggunakan buku rujukan berupa buku-buku tradisional atau terbitan lama mencapai 25 orang atau 89,29\%, sedangkan 
yang tidak setuju menggunakan buku rujukan dimaksud hanya mencapai 3 orang atau $10,71 \%$.

Dari data tersebut dapat dipahami bahwa dai di Bulukumba masih tradisional di dalam menggunakan buku rujukan.

Dai yang menggunakan buku rujukan yang berhubungan dengan pengetahuan yang berkaitan dengan metode keilmuan dalam perspektif Islam dan berkaitan dengan masalah kekinian mencapai 24 orang atau $85,71 \%$, sedangkan dai yang tidak menggunakan buku rujukan yang berhubungan dengan pengetahuan yang berkaitan dengan metode keilmuan dalam perspektif Islam dan berkaitan dengan masalah kekinian adalah hanya 4 orang atau $14,29 \%$.

Dari hal tersebut dapat diketahui bahwa dai telah menggunakan buku rujukan kontemporer sebagai sumber ilmu di dalam berdakwah di masyarakat.

Dengan memperhatikan karakteristik dai kontemporer di Bulukumba menunjukkan bahwa pada umumnya dai tergolong dai kontemporer, sebab dari beberapa ciri yang diajukan, seperti pengenalan terhadap istilah dai kontemporer, membaca konsep atau tidak dalam melaksanakan dakwah, penggunaan busana di dalam berdakwah, serta buku-buku rujukan yang digunakan, data menunjukkan terpenuhinya sebagian besar syarat. Oleh karena itu, dapat dikatakan bahwa salah satu ciri dakwah kontemporer adalah dai yang kontemporer.

\section{b. Materi Dakwah Kontemporer di Bulukumba}

Materi dakwah kontemporer merupakan materi dakwah yang telah dianalisis dan menyesuaikan dengan perkembangan zaman, namun tidak terlepas dari seluruh ajaran Islam yang meliputi akidah, ibadah, syariah, muamalah dalam arti luas, dan akhlaq. Bahkan dikatakan bahwa materi dakwah terkait dengan masalah-masalah yang berkaitan dengan kehidupan, masalah manusia, masalah harta benda, masalah ilmu pengetahuan dan masalah akidah. Materi dakwah ini bersumber dari Alquran dan Sunnah yang tidak terbatas. Dengan demikian, materi dakwah mencakup seluruh ajaran Islam, meliputi aqidah, syariat dan akhlak. Kesemuanya itu adalah ajaran Islam yang ditujukan kepada umat manusia.

Oleh karena itu, pemilihan materi yang tepat adalah penting bagi seorang mubalig, sehingga dakwah mempunyai peranan dalam menghadapi berbagai macam tipologi manusia. 
Salah satu ciri materi dakwah kontemporer adalah dai mampu menjelaskan materi-materi fikhi dengan mengaitkan masalah-masalah aktual dewasa ini, data menunjukkan bahwa terdapat 26 orang atau $92,86 \%$ dai yang sudah melaksanakan dakwah dengan mengangkat materi dakwah kontemporer yaitu mereka senantiasa menjelaskan materi-materi fikhi dengan mengaitkan masalah-masalah aktual dewasa ini. Sedangkan yang menyatakan tidak terdapat 2 orang atau $7,14 \%$.

Sedangkan dai yang telah menjelaskan alquran dan Sunnah secara kontekstual sebanyak 21 orang atau $75 \%$, sedang yang tidak menjelaskan alquran dan Sunnah secara kontekstual mencapai 7 orang atau $25 \%$.

Dengan demikian dapat diketahui bahwa dai lebih banyak yang telah melaksanakan salah satu ciri materi dakwah kontemporer yaitu senantiasa menjelaskan alquran dan Sunnah secara kontekstual.

Pada dasarnya dai di dalam melaksanakan dakwah di tengahtengah masyarakat senantiasa berdakwah dengan mengaitkan materi dakwahnya dengan budaya local, hal ini diketahui dari data yang diperoleh melalui angket bahwa dai yang telah menjelaskan materi dakwah dengan mengaitkan masalah budaya tradisional mencapai 26 orang atau $92,86 \%$, sedang yang tidak menjelaskan materi dakwah dengan mengaitkan masalah budaya tradisional mencapai 2 orang atau 7,14\%.

Data tersebut menunjukkan bahwa dai di Bulukumba telah banyak mengaitkan materi dakwahnya pada hal-hal yang berkaitan dengan budaya lokal dengan berbagai pendekatan dan strategi penerapannya.

Dai di dalam menjelaskan mengenai materi dakwah dengan mengaitkan masalah pilkada, issu korupsi, masalah ekonomi, masalah budaya tradisional dan perkembangan lainnya, diketahui bahwa terdapat 25 orang atau $89,29 \%$ yang telah menjelaskan seperti tersebut di atas, sedang yang tidak melaksanakannya hanya 3 orang atau $10,71 \%$.

Dengan demikian dapat dipahami bahwa dai di Bulukumba pada umumnya telah menguraikan materi dakwah berdasarkan kriteria materi dakwah kontemporer. Kriteria ini merupakan kriteria atau ciri dakwah kontemporer.

c. Penerapan Media Dakwah Kontemporer di Bulukumba

Banyak kalangan yang mensinyalir bahwa media sebagai bagian teknologi yang salah satu sistem yang ikut berperan dalam kehidupan 
sosial kemasyarakatan, termasuk pemanfaatannya sebagai media dakwah kontemporer.

Berdasarkan data dari hasil angket menunjukkan bahwa dai yang menggunakan laptop, smartphone, internet atau media modern dalam berdakwah hanya mencapai 8 orang atau $28,57 \%$, sedangkan yang tidak menggunakan laptop, smartphone, internet atau media modern dalam berdakwah mencapai 20 orang atau 71,43\%. Hal ini berarti, dai pada umumnya belum menggunakan media dakwah kontemporer di dalam berdakwah di Kabupaten Bulukumba.

Pelaksanaan dakwah melalui media cetak, seperti melalui Surat Kabar, Majalah, Tabloid dsb hanya mencapai 8 orang atau $28,57 \%$, sedangkan yang belum berdakwah lewat media cetak mencapai 20 orang atau $71,43 \%$. Memperhatikan hal tersebut, maka dikatakan bahwa dai di Kabupaten Bulukumba belum sepenuhnya menggunakan media cetak sebagai sarana berdakwah.

Adapun penggunaan media eletronik di dalam berdakwah digambarkan bahwa penggunaan media eletronik di dalam berdakwah hanya mencapai 6 orang atau $21,43 \%$, sedangkan yang belum menggunakan media eletronik di dalam berdakwah mencapai 22 orang atau $78,57 \%$. Hal ini menunjukkan bahwa dai belum sepenuhnya menggunakan media cetak dan eletronik khususnya media televisi, radio, film di dalam melaksanakan dakwah di Kabupaten Bulukumba.

Dengan demikian, dapat dikatakan bahwa salah satu ciri dakwah kontemporer adalah penggunaan media kontemporer di dalam berdakwah. Dari data tersebut dapat diketahui bahwa dai di Bulukumba belum sepenuhnya menggunakan media dakwah ini.

Oleh karena itu, dari ketiga ciri dakwah kontemporer, yaitu dai kontemporer, materi dakwah kontemporer dan media dakwah kontemporer oleh dai di Bulukumba baru berada pada lingkaran dai kontemporer dan materi dakwah kontemporer, sedangkan penggunaan media kontemporer belum sepenuhnya dimanfaatkan dengan baik, pada hal media inilah yang menjadi tolok ukur utama di dalam menilai apakah kegiatan dakwah dinilai kontemporer atau tidak adalah terpokus pada penggunaan media kontemporer ini.

Dengan demikian dapat dikatakan bahwa dai di Bulukumba belum termasuk melaksanakan dakwah kontemporer, tetapi baru pada tahap pengenalan media, sedang pada dai dan materi dakwahnya sudah tergolong kontemporer. 


\section{B. Peran Dakwah Kontemporer dalam Menangkal Radikalisme Agama di Bulukumba}

Kata Dakwah yang telah dikenal luas di kalangan masyarakat Indonesia tidaklah asing dan diberi arti seruan atau ajakan untuk memeluk dan mentaati ajaran-ajaran Islam. Dakwah Islam dapat diperluas dengan menyerukan kepada siapa saja untuk diajak memeluk Islam. Itulah sebabnya Islam disebut agama dakwah yakni agama yang disebarluaskan dengan cara damai tidak dalam bentuk kekerasan atau propaganda.

Sedangkan kontemporer adalah dapat bermakna semasa; sewaktu; pada masa kini; dewasa ini. ${ }^{14}$ Dari pengertian tersebut dapat dipahami bahwa istilah kontemporer adalah istilah yang terkait dengan masa dan masa yang dimaksud adalah masa sekarang atau era modern di dalamnya ditemukan alat-alat komunikasi yang serba canggih dan baru.

Berdasar dari uraian di atas, maka dapat dipahami bahwa dakwah kontemporer merupakan dakwah yang dilasanakan di era modern dengan menggunakan fasilitas teknologi modern.

Dengan adanya dakwah kontemporer, tidak berarti harus meninggalkan dakwah konvensional secara total, tetapi adanya upaya menyeimbangkan penggunaannya dan memperhatikan obyek dakwahnya.

Sedangkan radikalisme agama dipahami sebagai paham atau aliran yang menginginkan adanya perubahan paham agama dengan cara yang keras.

Dalam Kamus Besar bahasa Indonesia, kata 'radikal' memiliki arti "secara menyeluruh, habis-habisan; amat keras menuntut perubahan (undang-undang, pemerintahan, dsb); maju dalam berpikir atau bertindak". Kata 'radikalisme' berarti "paham atau aliran yang radikal dalam politik; paham atau aliran yang menginginkan perubahan atau pembaharuan sosial dan politik dengan cara keras atau drastis; sikap ekstrim dalam suatu aliran politik". ${ }^{15}$ Radikalisme dapat berubah menjadi terorisme. Kata 'terorisme' berasal dari kata 'teror' yang berarti "perbuatan (pemerintahan dsb) yang sewenang-wenang (kejam, bengis dsb); usaha menciptakan ketakutan, kengerian, dan kekejaman oleh seseorang atau golongan. Sedangkan kata 'teroris' berarti "Orang yang menggunakan kekerasan untuk menimbulkan rasa takut, biasanya

\footnotetext{
${ }^{14}$ Tim Penyusun Kamus Pusat Pembinaan dan Pengembangan Bahasa, Kamus Besar Bahasa Indonesia, h. 459.

${ }^{15}$ Tim Penyusun Kamus Pusat Pembinaan dan Pengembangan Bahasa, Kamus Besar Bahasa Indonesia, h. 718-719.
} 
untuk tujuan politik. ${ }^{16}$ Apabila terjadi perubahan sosial dan politik yang dilakukan oleh seseorang atau kelompok tertentu dan dapat menimbulkan kerusakan dan penderitaan secara fisik bagi orang lain.

Radikalisme juga dapat berubah menjadi fundamentalisme. Fundamentalisme dapat diartikan sebagai gerakan agama yang bereaksi terhadap perubahan sosial dan menganggapnya sebagai krisis. Mereka menyodorkan slogan kembali kepada agama otentik, namun cara untuk mencapai tujuannya berbeda dari tipe gerakan kebangkitan keagamaan lainnya. ${ }^{17}$ Apabila seseorang atau kelompok tertentu terjebak pada manipulasi teks-teks agama untuk membenarkan tindakan kekerasan yang mereka lakukan.

Semua agama mempunyai dua sisi yang memungkinkannya menjadi humanis, toleran, dan inklusif, tapi juga bisa menjadi agresif, fanatis, dan eksklusif. Para pengkaji Islam di Barat sejak awal telah membedakan antara Islam moderat, progresif, dan pluralis di satu sisi, dan Islam garis keras, konservatif, dan anti-pluralis di sisi lain. Dengan demikian, dapat memahami kenapa para penganut satu agama yang sama bisa berbeda dalam memperjuangkan aspirasinya. Penganut Hindu Gandhian begitu mendedikasikan hidupnya untuk perdamaian, berbeda dengan Hindu lain yang siap menghancurkan masjid dan rela mati dalam usahanya itu. Dalam tingkat 'ketaatan' yang sama, seorang muslim memusatkan aktivitasnya untuk membangun relasi harmonis antar umat beragama, sementara muslim yang lain bersemangat meledakkan tempattempat ibadah agama lain. Setelah melakukan pengembaraan jauh ke jantung khazanah Islam klasik, Nurcholish Madjid pernah menyimpulkan, semakin dekat dengan Islam periode Nabi, semakin toleran dan pluralis. Sebaliknya, semakin jauh dari periode Nabi, Islam semakin intoleran dan eksklusif. Hal ini bukan berarti umat Islam harus hidup seperti zaman Nabi, melainkan pemahaman agama yang sempit telah menyebabkan fanatisme dan intoleransi. Semakin luas dan mendalam pemahaman keagamaan seseorang, semakin toleran dan bisa bernegosiasi. ${ }^{18}$

Radikalisme dapat terjadi di berbagai wilayah, baik di dunia Islam maupun di luar dunia Islam, sebab radikalisme bisa bersifat universal dan

\footnotetext{
${ }^{16}$ Tim Penyusun Kamus Pusat Pembinaan dan Pengembangan Bahasa, Kamus Besar Bahasa Indonesia, h. 939.

${ }^{17}$ Mun'im A. Sirry, Membendung Militansi Agama: Iman dan Politik dalam Masyarakat Modern, (Jakarta: Erlangga, 2003), h. 4.

${ }^{18}$ Mun'im A. Sirry, Membendung Militansi Agama: Iman dan Politik dalam Masyarakat Modern, h. 104-116.
} 
terjadi dimana saja pada seluruh aspek kehidupan manusia tanpa mengenal agama dan budaya.

Menurut Tjamiruddin (Ketua MUI Bulukumba) menjelaskan bahwa dakwah yang menggunakan media atau sering disebut dengan dakwah kontemporer sangat memiliki peranan dalam menangkal issu-issu radikalisme agama, khususnya di Kabupaten Bulukumba. Oleh karena itu, para dai diharapkan mampu memahami dan memanfaatkan media ini, sehingga mereka dapat memahami dan mendeteksi adanya upaya penangkalan radikalaisme agama. ${ }^{19}$ Apabila para dai memahami perlunya menangkal radikalisme agama, maka mereka (dai) dapat menjadikannya sebagai benteng dalam menangkal radikalisme, terutama bila dikaitkan dengan posisi dai sebagai power yang dimilikinya sebagai citra dai. Hal ini sesuai dengan teori dakwah terkait dengan citra dai yaitu teori kredibilitas sumber (source credibility theory) yang telah diadopsi ke dalam praktik dakwah dengan nama teori citra dai, ${ }^{20}$ dijelaskan bahwa kualitas dan kepribadian seorang dai sangat menentukan tingkat keberhasilan dakwah. Kualitas yang dimiliki oleh seorang dai memengaruhi citranya di hadapan mad'u. Asumsi dasar teori ini adalah citra atau kredibilitas seorang dai sangat menentukan tingkat penerimaan mad'u terhadap pesan-pesan dakwah yang disampaikannya. Semakin tinggi kredibilitas seorang dai, maka semakin tinggi pula tingkat penerimaan mad'u terhadap pesanpesan dakwah yang disampaikannya. Seorang dai yang berkredibilitas tinggi adalah seorang yang mempunyai kompetensi di bidangnya, memiliki integritas kepribadian dan ketulusan jiwa. Ketika kredibilitas ini dimiliki oleh seorang dai, maka dia akan memiliki citra positif di hadapan mad'u.

Dakwah memiliki peran yang sangat besar terutama dalam menetralisir dampak pemahaman yang keliru terhadap gerakan radikal. Islam radikal tampaknya terus mencoba melawan. Perlawanan itu muncul dalam bentuk melawan kembali kelompok yang mengancam keberadaan mereka atau identitas yang menjadi taruhan hidup. Mereka berjuang untuk menegakkan cita-cita yang mencakup persoalan hidup secara umum, seperti keluarga atau institusi sosial lain. Mereka berjuang dengan

\footnotetext{
${ }^{19}$ Tjamiruddin (65 tahun), Ketua MUI Kabupaten Bulukumba, Wawancara, di Bulukumba pada taggal 5 Maret 2012

${ }^{20}$ Enjang AS. \& Aliyuddin Ilmu Dakwah: Pendekatan Filosofis \& Praktis. (Bandung: Widya Pajajaran, 2009), h. 120.
} 
kerangka nilai atau identitas tertentu yang diambil dari warisan masa lalu maupun konstruksi baru.

Sehubungan dengan itu, Muh. Ramli mempertegas bahwa bahaya laten radikalisme agama membawa pada kehancuran pandangan yang menganggap bahwa suatu cita-cita harus diraih dengan metode dan cara yang tidak manusiawi dan berperadaban. ${ }^{21}$

Paham radikalisme agama dapat saja memasuki wilayah-wilayah yang selama ini dianggap aman, namun kewaspadaan harus tetap ada, terutama daerah-daerah yang tidak jauh dari daerah yang terindikasi adanya paham radikalisme agama.

Radikalisme Islam sebagai bagian dari fenomena global. Radikalisme bukanlah khas Islam karena hal yang sama, dapat juga disaksikan dalam fundamentalisme Kristen di Amerika Serikat dan agama lain yang ada di Israil, India, Perancis, Jerman dan lain-lain. ${ }^{22}$

Sementara itu, Islam yang harmonis dapat dibuktikan dari peristiwa Fath Makkah (pembebasan Kota Makkah) oleh umat Islam yang dipimpin langsung Nabi Muhammad. Kota Makkah dibebaskan setelah puluhan tahun dijadikan markas kegiatan orang-orang musyrik. Saat umat Islam mengalami suasana euforia atas keberhasilannya menguasai kota tersebut, ada sekelompok kecil sahabat Nabi yang berpawai dalam kota dengan meneriakkan slogan "al-yaum yaumul malhamah" (hari ini adalah hari pertumpahan darah). Slogan itu dimaksudkan sebagai upaya balas dendam mereka atas kekejaman orang-orang musyrik Makkah kepada umat Islam selama puluhan tahun. Gejala tidak sehat tersebut dengan cepat diantisipasi oleh Nabi Muhammad dengan melarang beredarnya slogan itu dan menggantinya dengan slogan yang lebih ramah dan penuh kasih: al-yaum yaumul marhamah (hari ini adalah hari penuh belas kasih). Akhirnya, peristiwa pembebasan Kota Makkah dapat terwujud tanpa insiden berdarah. Gejala kemunculan radikalisme Islam sesungguhnya ditenggarai ada sejak Nabi Muhammad masih hidup.

Pengalaman dakwah para Nabi dan Rasul menunjukkan bahwa kondisi sosial yang dihadapi oleh Rasul secara fisik berbeda dengan kondisi sekarang, namun secara substansial medan dakwah Rasulullah

\footnotetext{
${ }^{21}$ Muh. Ramli (57 tahun), Mubalig, Wawancara, di Bulukumba pada tanggal 4 Maret 2012.

${ }^{22}$ Usman, Mencegah Radikalisme Agama: Dakwah Komunikatif Muhammadiyah di Sulawesi Selatan, Disertasi (Jakarta: Program Pascasarjana UIN Syarif Hidayatullah, 2010), h. 131-132.
} 
saw. memiliki kesamaan dengan tantangan dakwah dewasa ini. ${ }^{23}$

Setiap Nabi dan Rasul dalam melaksanakan dakwahnya senantiasa berhadapan dengan sistem dan struktur masyarakat yang di dalamnya terdapat beberapa struktur sosial, seperti: Al-mãla adalah orang-orang terkemuka di dalam masyarakat yang berperan sebagai penguasa (birokrat), pemimpin atau kepala suku yang selalu tampil dan menentukan arah bagi masyarakatnya. Al-mutrafin adalah kaum elit dalam bidang ekonomi, seperti: aghniyã dan konglomerat yang memiliki pengaruh besar dalam masyarakatnya. Al-mustad'afín biasanya adalah kaum mayoritas pengikut al-mãla atau kelompok yang biasanya tertindas oleh al-mãla dan al-mutrafin. Ketiga struktur sosial ini tampak jelas dalam dinamika dakwah Nabi Ibrahim as., Musa as., Isa as., dan Nabi Muhammad saw.

Usman dalam disertasinya berkesimpulan bahwa dakwah merupakan cara yang paling efektif untuk melawan radikalisme Islam, namun untuk mengatasinya tetap diperlukan cara-cara yang arif dan bijaksana. $^{24}$

Pada zaman Rasulullah dan sahabatnya terdapat beberapa tahapan dakwah yaitu: pertama, tahap pembentukan (takwin), kedua, tahap penataan (tandhim), ketiga, tahap perpisahan dan pendelegasian amanah dakwah kepada generasi penerus dalam haji wada (taudi). ${ }^{25}$ Teori tahapan dakwah ini memiliki proses jangka waktu yang panjang, sehingga tujuan dakwahpun dapat dicapai dengan melalui beberapa tahapan. Teori ini dapat ddijadikan sebagai acuan di dalam menangkal terjadinya radikalisme agama di Kabupaten Bulukumba.

Walaupun paham radikalisme agama di Bulukumba belum ditemukan dan indikasinya belum tercium, tetapi tetap perlu diwaspadai keberadaannya, terutama yang terkait dengan upaya pengalihan issu radikalisme agama tersebut.

\section{Kesimpulan}

Karakteristik dai kontemporer di Bulukumba menunjukkan bahwa pada umumnya dai tergolong dai kontemporer, sebab dari beberapa karakter yang diajukan, seperti pengenalan terhadap istilah dai kontemporer, membaca konsep atau tidak dalam melaksanakan dakwah,

\footnotetext{
${ }^{23}$ Munzier Suparta dan Harjani Hefni, Metode Dakwah, (Jakarta: Kencana, 2003), h. 21.

${ }^{24}$ Usman, Mencegah Radikalisme Agama: Dakwah Komunikatif Muhammadiyah di Sulawesi Selatan, h. 429

${ }^{25}$ Enjang AS. \& Aliyuddin, Ilmu Dakwah: Pendekatan Filosofis \& Praktis', h. 128.
} 
penggunaan busana di dalam berdakwah, serta buku-buku rujukan yang digunakan. Data menunjukkan terpenuhinya sebagian besar syarat. Oleh karena itu, dapat dikatakan bahwa salah satu karakter dakwah kontemporer adalah dai yang kontemporer.

Materi dakwah kontemporer di Bulukumba adalah terkait dengan strategi pembahasan materi dakwah yang ditampilkan oleh dai. Kriteria materi dakwah kontemporer yang diajukan adalah dai yang menjelaskan materi dakwah yang terkait dengan materi-materi fikhi dengan mengaitkan masalah-masalah aktual dewasa ini, dai menjelaskan materi dakwah dengan menjelaskan alquran dan sunnah secara kontektual, dai di dalam menjelaskan masalah-masalah agama dengan mengaitkan dengan masalah budaya tradisional serta kaitannya dengan issu-issu kotemporer seperti pilkada, korupsi, ekonomi, dan perkembangan lainnya. Berdasarkan hasil analisis penulis dikatakan bahwa pada umumnya dai di Bulukumba telah memenuhi syarat sebagai dai di dalam melaksanakan dakwah dengan menggunakan materi dakwah kontemporer.

Penerapan media dakwah kontemporer di Bulukumba karakteristik yang diajukaan adalah penggunaan media cetak dan eletronik di dalam berdakwah. Hasil penelitian menunjukkan bahwa dai di Bulukumba belum sepenuhnya menggunakan media kontemporer di dalam berdakwah. Dengan demikian dapat dikatakan bahwa dai di Bulukumba belum termasuk melaksanakan dakwah kontemporer, tetapi baru pada tahap pengenalan media, sedang pada dai dan materi dakwahnya sudah tergolong kontemporer.

Peran dakwah kontemporer dalam menangkal radikalisme agama telah berjalan, namun baru sampai pada upaya mengenalinya melalui media eletronik dan media cetak. Oleh karena itu, dakwah memiliki peran dan fungsi yang besar dalam menangkal radkalisme agama di Kabupaten Bulukumba.

Dakwah kontemporer adalah dai yang dalam melaksanakan dakwahnya senantiasa mengacu pada dai kontemporer. Oleh karena itu, perlu ditindak lanjuti dan dikembangkan terus karena mad'u lebih banyak meniru dari subyek dakwahnya. Materi dakwah kontemporer perlu lebih dikembangkan demi menjawab berbagai masalah yang ditimbulkan oleh keterbukaan dan kebebasan media. Media dakwah kontemporer yang merajai dunia dewasa ini perlu dimanfaatkan di dalam melaksanakan dakwah, agar para mad'u dapat mengakses ilmu agama lewat media kontemporer. Oleh karena itu disarankan kepada pihak-pihak yang berwewenang kiranya mendukung penggunaan media modern sebagai 
sarana dakwah. Itulah sebabnya, dai diperlukan paham betul penggunaan media, sehingga mereka juga mampu mengenali adanya pendangkalan paham kegamaan dan munculnya radikalisme agama.

\section{DAFTAR PUSTAKA}

Alquran al-Karim.

Ahmad, Amirullah, t. th. Struktur Keilmuan Dakwah: Sebuah Kajian Epistemologi dan Struktur Keilmuan Dakwah Islam Sebagai Ilmu.

Anas, Ahmad, 2006, Paradigma Dakwah Kontemporer: Aplikasi Teoriotis dan Praktis Dakwah Sebagai Solusi Problematika Kekinian. Semarang: Pustaka Rizki Putra.

Arifin, Anwar, 2011, Dakwah Kontemporer: Sebuah Studi Komunikasi. Cet I; Yogyakarta: Graha Ilmu.

BPS, 1990, Bulukumba dalam Angka tahun 1990.

BPS, 2011, Bulukumba dalam Angka tahun 2011.

Cangara, Hafied, 2011, Komunikasi Politik, Teori dan Strategi. Cet. III; Jakarta: Rajawali Pers.

Enjang AS. \& Aliyuddin, 2009, Ilmu Dakwah: Pendekatan Filosofis \& Praktis. Bandung: Widya Pajajaran.

Enjang AS. \& Aliyuddin, t. th. Ilmu Dakwah: Pendekatan Filosofis \& Praktis. Bandung: Widya Pajajaran.

Kalla Group, 2015, Alquran dan Terjemahnya, Semarang, PT. Karya Toha Putra.

Kasman, Suf, 2010, Pers dan Pencitraan Umat Islam di Indonesia; Analisis Isi Pemberitaan Harian Kompas dan Republika. Cet. I; Jakarta: Balai Litabang dan Diklat Kementerian Agama RI.

Muhammad, Hasyim. Khoirul Anwar, Misbah Zulfa E., 2015, Diskursus Deradikalisasi Agama: Pola Resistensi Pesantren Terhadap Gerakan Radikal, Jurnal Walisongo, Volume 23, Nomor 1.

Munip, Abdul. 2012, Menangkal Radikalisme Agama Di Sekolah, Jurnal Pendidikan Islam : Volume I, Nomor 2 
Rokhmad, Abu. 2012, Radikalisme Islam Dan Upaya Deradikalisasi Paham Radikal, Jurnal Walisongo, Volume 20, Nomor 1.

Rokhmad, Abu. 2014, Pandangan Kiai Tentang Deradikalisasi Paham Islam Radikal Di Kota Semarang, Jurnal "Analisa" Volume 21 Nomor 01

Severin, Werner J. dan James W. Tankard, Jr. 2009, Communication Theories: Origins, Methods, \& Usis in the Mass Media. Terj. Sugeng Hariyanto. Cet. IV; Jakarta: Kencana.

Sirry, Mun'im A. 2003, Membendung Militansi Agama: Iman dan Politik dalam Masyarakat Modern. Jakarta: Erlangga.

Sivan, Emmanuel, 1985, Radical Islam: Medieval Theology and Modern Polities, Yale University Press, Enlarged Edition.

Soekanto, Soerjono, 2007, Sosiologi Suatu Pengantar. Jakarta: Raja Grafinda Persada.

Suparta, Munzier dan Harjani Hefni, 2003, Metode Dakwah. Jakarta: Kencana.

Tibi, Basam, 2002, The Challenge of Fundamentalism: Political Islam and the New World Disorder, London: Univerity of California Press.

Tim Penyusun Kamus Pusat Pembinaan dan Pengembangan Bahasa, 1989, Kamus Besar Bahasa Indonesia. Cet. III; Jakarta: Balai Pustaka.

Usman, 2010, Mencegah Radikalisme Agama: Dakwah Komunikatif Muhammadiyah di Sulawesi Selatan, "Disertasi", Jakarta: Program Pascasarjana UIN Syarif Hidayatullah.

Zada, Khamami, 2002. Islam Radikal: Pergumulan Ormas-ormas Islam Garis Keras di Indonesia. Jakarta: Teraju. 